\title{
Greenland ice cap aeromagnetic survey 1985 : magnetic measurements over the southern end of the Greenland ice cap
}

\author{
L. Thorning, M. Bower, C. D. Hardwick and P. J. Hood
}

In continuation of previous aeromagnetic survey work in 1983 and 1984 (Thorning et al., 1984, 1985) operations were carried out in April 1985 over a part of the Greenland ice cap south of the area surveyed in 1984. The reconnaissance lines flown in 1984 gave reason to expect that the geological structures in this part of Greenland would be reflected in the aeromagnetic field. This proved to be the case. The GICAS project is a cooperation between the Geological Survey of Greenland (GGU), the Geological Survey of Canada (GSC), and the National Aeronautical Establishment (NAE) of the National Research Council of Canada.

\section{The field operation}

The flights were carried out in April 1985 from Søndre Strømfjord and Narssarssuaq, again using the NAE Convair 580 Aircraft (C-FNRC) (Hardwick, 1982). Severe storms with wind velocities up to $100 \mathrm{knots}$ in some parts of the target area made the flight operations difficult, and the original plans calling for a complete survey of the part of the ice cap lying east of $46^{\circ} \mathrm{W}$ had to be changed in the field because surveying over the east coast of Greenland was impossible. Instead nine lines were flown just west of $46^{\circ} \mathrm{W}$. For similar reasons most parts of the lines south of $61-62^{\circ} \mathrm{N}$ had to be given up. The resultant distribution of lines is shown in fig. 1, and comprises some 9600 line $\mathrm{km}$ of good quality data.

The surveying parameters were as in previous operations, and the base station recording of diurnal magnetic variations took place in Narssarssuaq. A novel improvement in the Convair 580 instrumentation allowed production of profile plots of data while still in Greenland.

\section{Results}

As in the region north of this year's survey area, many well-defined anomalies were discovered. Most of the data are shown as a profile map in fig 2 . The line to line correlation is evident although somewhat obscured by the varying proximity of the magnetic sources. The Archaean-Ketilidian boundary is seen as a broad magnetic low all the way across Greenland. Many structures in the Archaean block north of this are reflected in the magnetic field, and the granite belt to the south is seen as a broad magnetic high. An intriguing anomaly has been detected at approximately $63^{\circ} \mathrm{N}, 47^{\circ} 30^{\prime} \mathrm{W}$. It is by far the largest anomaly yet observed above the ice cap, its amplitude is one order of magnitude above that of other anomalies in the area so far surveyed. Its position can be seen on fig. 2 (note top of anomaly has been cut off for clarity), and in fig. 3 two additional profiles over the anomaly are shown. It is almost circular (approximately 6 by $7 \mathrm{~km}$ ), although the anomaly seems to be composite judged from the north-south profile which exhibits two maxima. The thickness of the ice is here approximately $1 \mathrm{~km}$, and the flight altitude $330 \mathrm{~m}$ over the surface. Rule-of-thumb depth determinations indicate a depth of approximately $1.5 \mathrm{~km}$ to the source, which means that it is an 


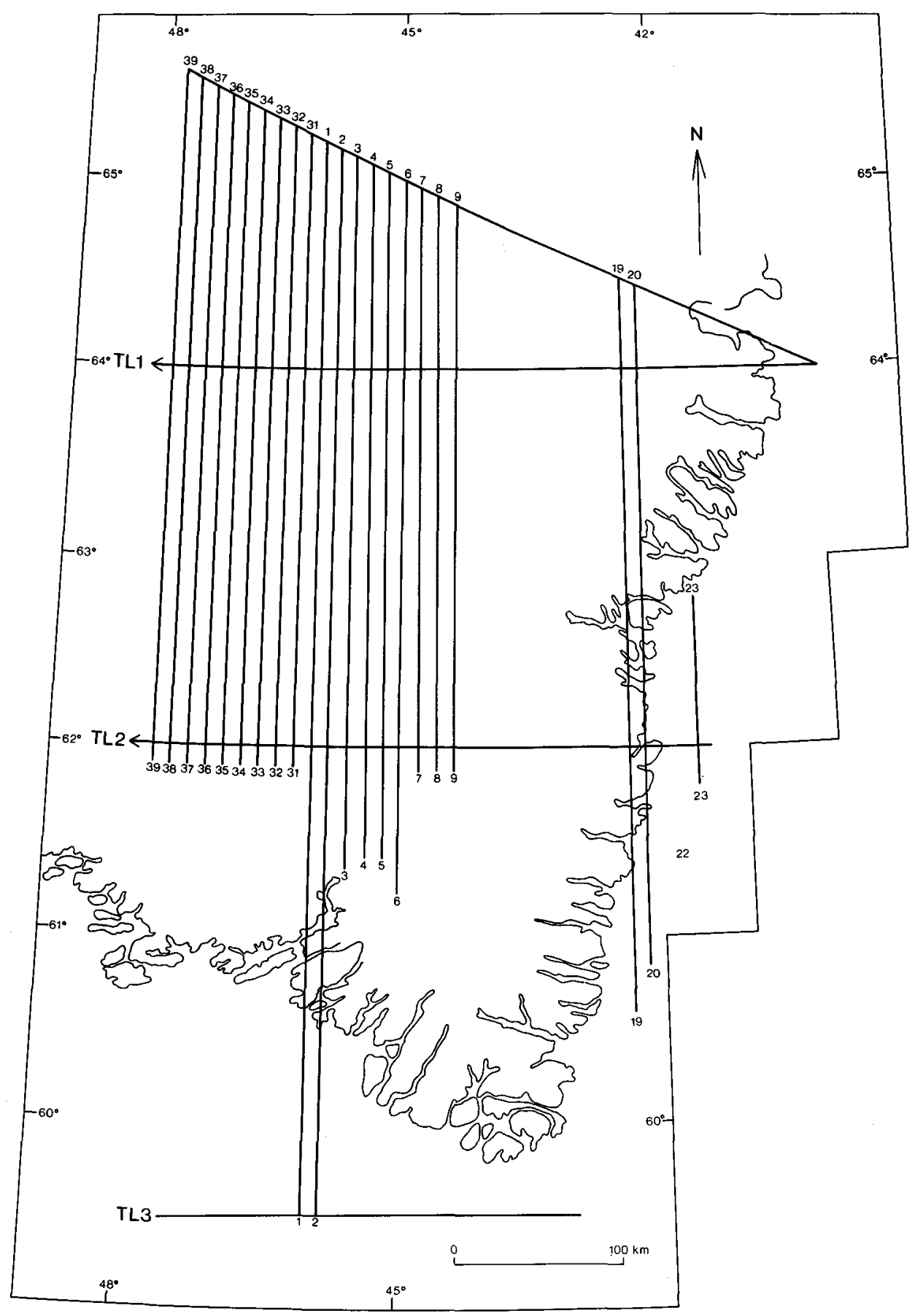

Fig. 1. Schematic representation of lines flown during the operations in April 1985. Not shown is one line along $50^{\circ} \mathrm{W}$. Tie lines were continued to offshore West Greenland. Approximately 9600 line $\mathrm{km}$ were acquired in 10 flights. 


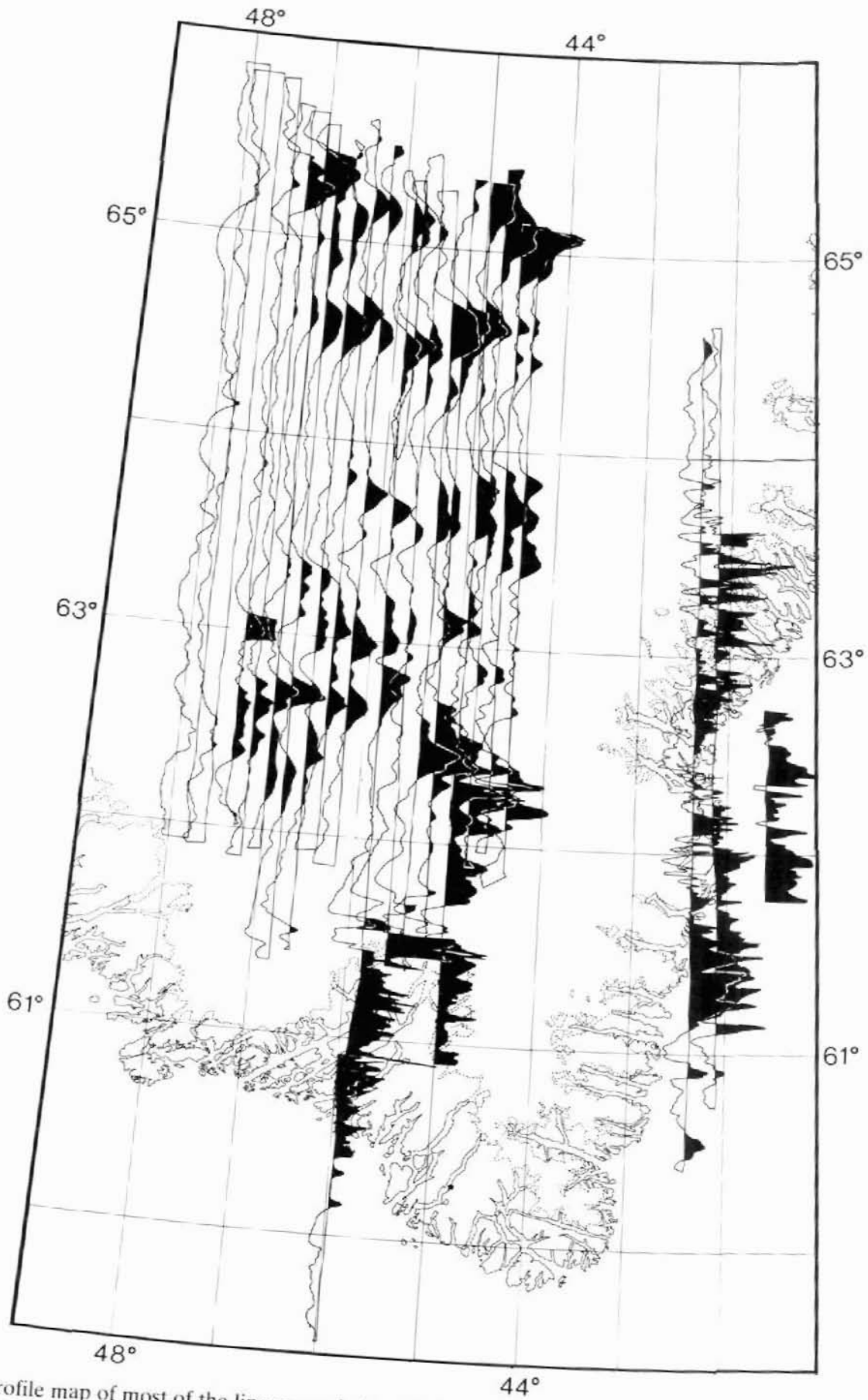

Fig. 2. Profile map of most of the lines recorded in $44^{\circ}$

bly contaminated by strong diurnal level shifts. The 1985 . Note the westernmost two profiles are prob. low its maximum value. 

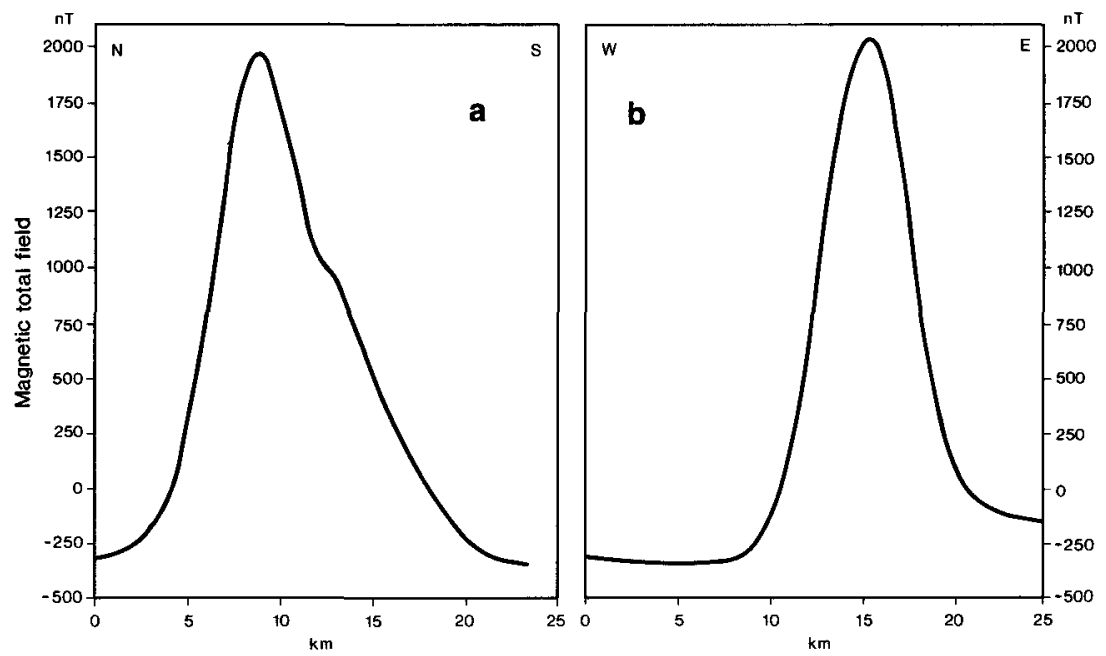

Fig 3. Magnetic profiles across the anomaly at $63^{\circ} \mathrm{N}, 47^{\circ} 30^{\prime} \mathrm{W}$. (a): north-south. (b): east-west.

intra-basement structure of highly magnetic rocks. This is of course a fascinating object of study, but equally rewarding information will be gained by the study of the regional magnetic anomalies.

\section{Further work}

The data acquired in 1985 will be compiled with those from 1984 and new data which will be acquired in 1986 and will complete the coverage of the southern part of the Greenland ice cap so that a magnetic anomaly map over southern and central Greenland can be produced. Recently, most of the existing aeromagnetic data from Greenland have been included in the data base for the new magnetic anomaly map of the North American continent. The new GICAS data allow geological structures to be followed all the way from Canada over Greenland to the Atlantic margin off East Greenland.

Acknowledgements. The following participated in the field operations besides the authors: W. T. Chevrier (aircraft commander), J. Aitken (pilot), R. Lee, B. Rudra (project crew), D. H. Stevens (project crew, maintenance crew chief), J. Beaudry, S. O'Connor and D. Blythe (maintenance crew), all from NAE, and E. Hansen (electronics engineer) from GGU. K. Frellesvig (computing consultant) handled the transfer of the data into GGU's data base. Field work and subsequent processing were supported by the Danish Natural Science Research Council (J. No. 11-4985).

\section{References}

Hardwick, C. D. 1982: Benefits of NAE 3-axis magnetic gradiometer. The Northern Miner 68(24), B1B2.

Thorning, L., Bower, M., Hardwick, C. D. \& Hood, P. J. 1984: Greenland ice cap aeromagnetic survey 1983: acquisition of high sensitivity total field and gradient magnetic data. Rapp. Grønlands geol. Unders. 120, 32-36. 
Thorning, L., Bower, M., Hardwick, C. D. \& Hood, P. J. 1985: Greenland ice cap aeromagnetic survey 1984: reconnaissance lines in southern Greenland. Rapp. Grønlands geol. Unders. 125, 83-84.

C. D. H.,

Flight Research Laboratory, National Research Council, Montreal Road, Ottawa, Ontario, Canada, K1A 0R6.
M. B.,

Flight Research Section, Bldg. U-61, National Research Council, Montreal Road, Ottawa, Ontario, Canada, K1A 0R6.
P. J. H.,

Regional Geophysics Subdivision, Resource Geophys. \& Geochem. Div., Geological Survey of Canada, 601 Booth Street, Ottawa, Ontario, Canada, K1A 0E8.

\title{
Reconnaissance dating of Archaean rocks from South-East Greenland
}

\author{
J. C. Escher, F. Kalsbeek, O. Larsen, T. F. D. Nielsen and P. N. Taylor
}

A major project of geological investigations in South-East Greenland is planned for 1986 and 1987 with the aim of producing sheet 14 of the 1:500 000 geological map series covering Greenland. The northern part of the map sheet is occupied by the Nagssugtoqidian mobile belt, and the southern part consists mainly of Archaean rocks. Because of difficulties of access, the Archaean part of the area is poorly known. Geological reconnaissance has been carried out by Bridgwater \& Gormsen (1969), and, as a preparation for the 1986 and 1987 expeditions, by Escher \& Nielsen $(1982,1983)$ and Nielsen \& Escher (1985). This report presents reconnaissance $\mathrm{Rb}-\mathrm{Sr}$ and $\mathrm{Pb}-\mathrm{Pb}$ whole-rock age determinations from the Archaean part of the map sheet.

\section{General geology}

The following summary (see Nielsen \& Escher, 1985; and papers quoted therein) is exclusively based on short reconnaissance visits and a single survey from the air, and may have to be reconsidered after more detailed mapping. The Archaean terrain (fig. 1) is composed of a granulite facies core region of brownish agmatitic hypersthene-bearing gneisses and brownish migmatitic agmatites with meta-igneous inclusions ranging from ultramafic to dioritic. The core region is surrounded to the north, west and south by grey agmatitic amphibolite facies gneisses with, often large, mafic inclusions and with several major isoclinally folded supracrustal units, dominated by amphibolites. These two major metamorphic complexes are commonly separated by intrusive rocks: charnockites, gabbros, and rocks of dioritic to granitic composition. Where the boundary between the high-grade core and the grey gneisses is not obscured by intrusions, a prograde metamorphic transition is found.

$\mathrm{A}$ few $\mathrm{K}$-Ar and ${ }^{40} \mathrm{Ar}-{ }^{39} \mathrm{Ar}$ ages (on whole-rock samples, hornblende and biotite) have been reported from the area, and range from c. 2700 - c. 2200 Ma (Larsen, 1969; Bridgwater, 1970, 1971). A single U-Pb 'diffusion' age of $2808 \mathrm{Ma}$ has been obtained for zircons from supracrustal rocks near Tingmiarmiut (quoted in Pedersen et al., 1974) and presumably 